\title{
İPOTEK HAKKININ HACZİ İLE İLGİLİ SORUNLAR VE DEĞERLENDİRME
}

\author{
Av. Dr. Uğur BULUT
}

\begin{abstract}
ÖZET
Türk hukuk uygulamasında kabul gören ipotek hakkının haczi müessesesi, ipotek hakkının maddî hukukta düzenlenen nitelikleri bakımından tartışmaya açıktır. Zira, maddî hukuk kurallarına göre ipotek hakkının asıl alacak hakkından bağımsız bir niteliği ve asıl alacaktan ayrı olarak tek başına hukukî işlemlere konu edilebilmesi söz konusu değildir. Yine esasen icra hukukunda haciz müessesesi bakımından da maddî hukuk kurallarından tamamen bağımsız bir uygulama söz konusu değildir. Bu çerçevede, maddî hukuka göre tek başına başkasına devri mümkün olmayan hakların haczi kabul görmemektedir. Bu kural, İcra ve İflâs Kanunu'nda düzenlenen haczi caiz olmayan mal ve haklar haricinde, haczin amacından hareketle ortaya çıkan genel bir kural niteliğindedir. Bu nedenle, devredilebilir olma herhangi bir mal veya hakkın haczedilebilir olmasının bir ön koşuludur. O hâlde, ipotek hakkının haczi bakımından da bu hakkın maddî hukukta kabul gören özellikleri ile haczedilebilir mal ve hakların genel kuralları çerçevesinde bir değerlendirme yapılmalı ve ipotek hakkının münhasıran haczi mümkün olmamalıdır.
\end{abstract}

Anahtar Kelimeler: Haciz, İpotek, Devredilebilir, Alacak Hakkı, Fer’̂̀ Hak.

İzmir Barosu, av.ugurbulut@gmail.com, ORCID ID: 0000-0002-4347-1799,

(Geliş Tarihi: 31.01.2019 - Kabul Tarihi: 04.03.2019) 


\title{
ASSESSMENT AND PROBLEMS ABOUT THE SEZIURE OF HYPOTHEC
}

\begin{abstract}
It is arguable to seize the right of hypothec, which is accepted widely in Turkish law practice, with regard to characteristics of hypothec that is constructed in substantive law. Then, according to substantive law regulations, the right of hypothec is not independent from the principal claim and can not be subject to legal transactions exclusively. Likewise, the rules of seizure in enforcement law are not actually independent from the fundamentals of substantive law. Therefore, it is not accepted to seize rights that cannot be transferred to others exclusively according to substantive law. This rule is a general recognition based on the aim of the seizure along with the special provisions about the non-distrainable goods and rights regulated in Turkish Code of Execution and Bankruptcy. Hence, to be transferable is a prior condition in order to be seizable for any rights and goods. Therefore, law practice about the seizure of the right of hypothec should also be reviewed under the characteristics of this right accepted in substantive law and general limitations about the non-distrainable goods and rights; and, it should not be accepted to seize a right of hypothec exclusively.
\end{abstract}

Keywords: Seizure, Hypothec, Transferrable, Right to Claim, Accessory Rights. 


\section{GİRIŞ}

İcra hukukunda haciz kurumu ile alacaklının alacağına kavuşması sürecinde paraya çevrilecek borçluya ait mal ve haklara hukuken el konulmaktadır. Kural olarak, borçluya ait bütün malvarlığı değerlerine haciz konulması mümkündür. Haciz, paraya çevirme aşamasından bir önceki takip aşaması olduğundan devredilemez olması nedeniyle paraya çevrilmesi mümkün olmayan mal ve hakların haczi de caiz değildir. Bu husus haciz kurumunun niteliği gereği karşımıza çıkmaktadır.

$\mathrm{Bu}$ çerçevede, takip borçlusunun üçüncü bir kişiden olan alacak haklar1nın haczedilmesi kural olarak mümkün olmakla beraber, bu alacak hakkının teminatını oluşturan ipotek hakkının da ayrıca haczedilmesi tartışmaya açık bir uygulamadir.

Çalışmamızda öncelikle ipoteğin maddî hukuk bakımından özellikleri ve asıl alacakla bağlantısı üzerinde durulmuş ve daha sonra icra hukukunda haczedilebilirliğe ilişkin genel kurallara değinilmiştir. Son bölümde ise, ipotek hakkının haczine ilişkin uygulama üzerinde durularak ipotek hakkının maddî hukukta kabul gören niteliği ve icra hukuku sistemimizin haciz aşamasına ilişkin kuralları çerçevesinde ipotek hakkının haczine dair uygulamaya yönelik değerlendirmelerde bulunulmuştur. Bu çerçevede, ipotek hakkının tek başına haczinin mümkün olup olmadığı yanında, esasen böyle bir uygulamaya gerek olup olmadığı da tartışılmıştır.

\section{IPOTEK HAKKI BAKIMINDAN GENEL BİLGI}

\section{A. İPOTEK HAKKI}

Türk Medenî Kanunu'nun 881 ilâ 897. maddeleri arasında düzenlenen ipotek, mevcut ya da ileride doğması muhtemel kişisel bir alacağ ${ }^{1}$ güvence al-

Teminat altına alınan alacak hakkının para alacağı dışında paradan başka bir şey verme, yapma veya yapmama borçları da olması mümkündür. Böyle bir durumda, borç gereği gibi yerine getirilmezse alacaklının uğrayacağı zarar için para olarak talep edilecek tazminatın teminat altına alınması söz konusudur. Bu konuda bkz. Tekinay, Selâhattin Sulhi (1994) Menkul Mülkiyeti ve Sınırlı Aynî Haklar, İstanbul, Filiz, s. 107; Oğuzman, M. Kemal/Seliçi, Özer/Oktay-Özdemir, Saibe (2018) Eşya Hukuku, 21. Baskı, İstanbul, Filiz, s. 960; Nomer, Haluk Nami/Ergüne, Mehmet Serkan (2016) Eşya Hukuku, C: II Rehin Hukuku, İstanbul, Oniki Levha, s. 42; Sirmen, A. Lâle (2018) Eşya Hukuku, 6. Baskı, Ankara, Yetkin, s. 631; Ayan, Mehmet (2017) Eşya Hukuku III Sınırlı Aynî Haklar, 8. Baskı, Ankara, Seçkin, s. 218; Esener, Turhan/Güven, Kudret (2015) Eşya Hukuku, 6. Baskı, Ankara, Yetkin, s. 498; Ünlütepe, Mustafa (2012) 'İpoteğin Alacak Hakkı Bakımından Kapsamı', Türkiye Barolar Birliği Dergisi, S:102, s. 176 vd. 
tına almak amacıyla, kıymetli evraka bağlanmaksızın, bir taşınmazın değerinden alacaklının alacağını elde etmesine imkân tanıyan sınırlı aynî hak olarak tanımlanabilir ${ }^{2}$. İpotek, alacaklıya yalnızca paraya çevirme yetkisi veren bir hak olup bu yetki sadece alacağın muaccel olmasıyla aktifleşmektedir³.

Türk Medenî Kanunu'nun 881. maddesinde belirtildiği üzere ipoteğin borçluya ait bir taşınmaz üzerinde kurulması şart olmadığı gibi, borçluya ait bir taşınmaz üzerinde ipotek kurulmasından sonra borçlunun bu taşınmazın mülkiyetini devretmesine de engel yoktur ${ }^{4}$. Bu nedenle, borçtan şahsî sorumluluğu olan borçlunun mülkiyetinde olmayan bir taşınmaz üzerinde de ipotek kurulmuş olabilir.

İpoteğin tanım ve amacından anlaşılabileceği gibi, ipoteğin varlığı teminatın konusunu oluşturan başka bir alacağın varlığına bağlıdır. Bu çerçevede,

2 Bkz. Tekinay, s. 106; Akipek, Jale G. (1974) Türk Eşya Hukuku (Aynî Haklar), Üçüncü Kitap Mahdut Aynî Haklar, Ankara, Sevinç, s. 162-164; Akipek, Jale G./Akıntürk, Turgut (2009) Eşya Hukuku, İstanbul, Beta, s. 786-787; Gürsoy, Kemal T./Eren, Fikret/Cansel, Erol (1984) Türk Eşya Hukuku, 2. Baskı, Ankara, Ankara Üniversitesi Hukuk Fakültesi, s. 1032; Köprülü, Bülent/Kaneti, Selim (1982) Sınırlı Aynî Haklar, 2. Baskı, İstanbul, Fakülteler, s. 262; Serozan, Rona (2006) 'Taşınmaz Rehni', İstanbul Üniversitesi Hukuk Fakültesi Mecmuası, C:64, S:2, s. 301, 305; Kuntalp, Erden (1995) 'Teminat Kavram1, Teminat Türleri ve Bunlardan Doğan Sorumluluk', Reha Poroy’a Armağan, İstanbul, İstanbul Üniversitesi Hukuk Fakültesi, s. 280 vd; Aybay, Aydın/Hatemi, Hüseyin (2012) Eşya Hukuku, 3. Baskı, İstanbul, Vedat, s. 275; Oğuzman/Seliçi/Oktay-Özdemir, s. 960; Ayan, s. 217-218; Altay, Sümer/Eskiocak, Ali (2007) Türk Medeni Hukukunda Taşınmaz Rehni, İstanbul, Vedat, s. 211; Şener, Yavuz Selim (2010) Türk Hukukunda İpotek ve Uygulaması, 3. Baskı, Ankara, Adalet, s. 5; Çetiner, Bilgehan (2015) Taşınmaz Teminatı, İstanbul, Filiz, s. 99 vd; Barlas, Nami (2003) 'Yeni Medenî Kanunun Aynî Teminatlara İlişkin Düzenlemeleri', Bilgi Toplumunda Hukuk, Ünal Tekinalp'e Armağan, C:2, İstanbul, Beta, s. 570 vd; Schmid, Jörg/Hürlimann-Kaup, Bettina (2012) Sachenrecht, 4. Auflage, Zürich-Basel-Genf, Schulthess, Rdnr. 1597 vd; Gödde, Walter (1980) Grundpfandrechte, Wiesbaden, Springer, s. 30; Wolf, Manfred/Wellenhofer, Marina (2018) Sachenrecht, 33. Auflage, München, C.H.Beck, 26, Rdnr. 1; Lüke, Wolfgang (2018) Sachenrecht, 4. Auflage, München, C.H.Beck, §18, Rdnr. 674.

3 Akipek, s. 175; Ayan, s. 197; Acar, Faruk (2015) Rehin Hukuku Dersleri, İstanbul, Vedat, s. 57.

4 Tekinay, s. 110, 114; Akipek, s. 228-229; Saymen, Ferit H./Elbir, Halid K. (1954) Türk Eşya Hukuku (Aynî Haklar), İstanbul, Akgün, s. 616, 620; Gürsoy/Eren/Cansel, s. 1035; Akipek/Akıntürk, s. 788; Köprülü/Kaneti, s. 380-381, 384; Serozan, s. 313; Kuntalp, s. 292-293; Oğuzman/Seliçi/Oktay-Özdemir, s. 970; Aybay/Hatemi, s. 285, 287; Nomer/Ergüne, s. 44; Sirmen (2018), s. 636; Ayan, s. 221; Budak, Ali Cem (2010) İpoteğin Paraya Çevrilmesi Yoluyla Takip, 3. Baskı, İstanbul, Oniki Levha, s. 99; Schmid/Hürlimann-Kaup, Rdnr. 1606, 1618; Gödde, s. 33; Wolf/Wellenhofer, $₫ 27$, Rdnr. 11, 59. 
alacağın hukuksal varlığındaki değişiklikler alacak hakkının teminatı olan ipoteği de etkilemektedir. İpotek ile teminatını oluşturduğu alacak hakkı arasındaki bu sıkı bağlantıya bir sonraki başlık altında detaylı olarak değinilmiştir. Esasen yine bu bağlantı sebebiyle ipotek hakkı tedavül kabiliyetini haiz olmayıp bu hakkın kıymetli evraka bağlanması da mümkün değildir ${ }^{5}$. Türk Medeni Kanunu'nun 882. maddesinin ikinci fikrasında da bu husus açıkça düzenlenmiş ve alacaklıya verilen ipoteği gösteren belgenin kıymetli evrak niteliğinde olmadığı belirtilmiştir.

\section{B. İPOTEK HAKKININ BAĞIMSIZ NITELİĞİ OLUP OLMADIĞI}

İpotek hakkı, belirli bir kişisel borcun teminatı olarak alacaklıya ek imkânlar sağlamakta ve alacaklı için aynî bir güvence oluşturmaktadır. Ancak buna rağmen tek başına bir ipotek hakkının, asıl alacaktan bağımsız olarak ve gerektiğinde asıl alacağın varlığı iddia ve ispat edilmeksizin herhangi bir sonuç doğurması mümkün değildir. Doktrinde de ipotek hakkının bağımsız bir varlığının söz konusu olamayacağı ${ }^{6}$, asıl alacaktan ayrı olarak tek başına bir ipotek hakkının olamayacağ ${ }^{7}$, ipoteğin alacaktan hiçbir surette ayrılamayacağ ${ }^{8}$, böyle bir ipotek hakkının faydasız olacağı dile getirilmiştir9. Nitekim, doğrudan konuyla ilgili olmasa dahi Yargıtay kararlarında da ipotek hakkının bağımsız bir varlığının söz konusu olamayacağı, ancak bir alacak hakkının fer'î niteliğinde olabileceği kabul edilmiştir ${ }^{10}$.

Ayiter, Nuşin (1977) Eşya Hukuku, Ankara, Sevinç, s. 178; Akipek, s. 228; Saymen/Elbir, s. 618; Gürsoy/Eren/Cansel, s. 1034; Köprülü/Kaneti, s. 378; Aybay/Hatemi, s. 285; Acar, s. 67; Nomer/Ergüne, s. 41; Ayan, s. 220; Aktepe, Sezin (2007) 'İpoteğin Alacağa Bağlı Hak Olması ve Diğer Özellikleri’ İstanbul Ticaret Üniversitesi Sosyal Bilimler Dergisi, S:12, s. 179; Ernst, Wolfgang/Zogg, Samuel 'Die Grundpfandverschreibung': Honsell, Heinrich/Vogt, Nedim Peter/Geiser, Thomas (Editörler) (2011) Bundesgesetz über Schuldbetreibung und Konkurs I, 2. Auflage, Basel, Helbing \& Lichtenhahn, Vor. Art 824-835, Rdnr. 2, 7.

6 Bertan, Suad (1976) Aynî Haklar, C:2, Ankara, Balkan, s. 1576.

7 Wieland, Carl Albert (1909) Das Sachenrecht des schweizerischen Zivilgesetzbuchs, Zürich, Schulthess (Çeviren: Karafaki, İ. Hakkı (1946) Aynî Haklar, Ankara, Yeni Cezaevi), s. 631; Wolfgang/Zogg, Vor. Art 824-835, Rdnr. 4; Wolf/Wellenhofer, \$27, Rdnr. 3, 11.

Ayiter, s. 181.

Acar, s. 9, 37.

“...ipotek hakkının bağımsız bir varlığı olamaz. İpotek hakkı ancak alacak hakkının fer'i olur. İpoteklerde ana hak kişiler arasında bir hukuki bağdan doğan şahsi bir borç münasebetidir. 
İpoteğin alacağa bağlılığın bir sonucu olarak, teminat altına alınan alacağın devri hâlinde ipotek de kendiliğinden yeni alacaklıya geçer (TBK m. $189 / 1)^{11}$. Zira, ipotekli alacağın devrinde, ipotek hakkı alacak hakkına mutlak olarak bağlıdır ${ }^{12}$. Bunun için alacağın devredildiğinin tapu siciline tescil edilmesi de şart değildir (TMK m. 891) ${ }^{13}$. Yine ipoteğin asıl alacağa bağlı bir hak

İpotekte ayni hak amaç değil, bir emniyet sağlama çağrısıdır.” İBK, 02.04.2004, 2003/1, 2004/1 <http://www.kazanci.com> s.e.t. 20.02.2019.

11 Ayiter, s. 181; Tekinay, s. 107, 117; Akipek, s. 227, 233; Saymen/Elbir, s. 623-624; Gürsoy/Eren/Cansel, s. 1042; Köprülï/Kaneti, s. 378, 390; Serozan, s. 305, 311, 315; Aybay/Hatemi, s. 285; Oğuzman/Seliçi/Oktay-Özdemir, s. 964; Sirmen, Lale (2006) 'İpotekli Alacağın Devredilmesi ile İlgili Bazı Sorunlar', Ticaret Hukuku ve Yargitay Kararları Sempozyumu XXII, 15 Aralık 2006, s. 218; Çetiner (2015), s. 135; Acar, s. 11; Nomer/Ergüne, s. 43; Ayan, s. 219-220, 240; Özçelik, Ş. Barıș (2017) 'İpoteğin Alacağa Bağlilığı', Banka ve Ticaret Hukuku Dergisi, C:33, S:4, s. 172; Wieland, s. 616, 664; Wolfgang/Zogg, Art. 835; Schmid/Hürlimann-Kaup, Rdnr. 1615; Gödde, s. 32; Lüke, $\$ 18$, Rdnr. 697; “...bu durumda, temlik al1nan kısım kadar ipotek hakkının da TBK'nun 189. maddesinde yer alan emredici düzenleme gereğince temlik alacaklısına geçeceği tabii olup, .... Noterliği'nin 17.9.2013 tarih ve 27416 yevmiye numaralı alacağın temliki sözleşmesinin 2. bendinde, ipotek hakkının da açıkça devredildiği, söz konusu bentteki düzenleme olmasaydı dahi, Kanunun emredici hükmü gereğince alacağın devri ile bağlı haklardan olan ipotek hakkının da intikal edeceği gerçeği karşısında, mahkemenin, temliknamede alacağın devri ile beraber ipotek hakkının devredilmediği yönündeki gerekçesi yerinde değildir.” 12. HD, 31.05.2016, 12833/15402 <http://www.kazanci.com> s.e.t. 20.02.2019.

12 Çetiner (2015), s. 134-135; Sirmen (2018), s. 633; Ayan, s. 219; Aktepe, s. 182; Schmid/Hürlimann-Kaup, Rdnr. 1602-1603; Gödde, s. 30. Benzer yönde bkz. Köprülü/Kaneti, s. 377.

Bu bağlllı̆̆ın tek yönlü olduğu, ipotek hakkı devredilmeksizin alacak hakkının devredilebileceği; ancak, alacak hakkı devredilmeksizin ipoteğin devredilemeyeceği hakkında bkz. Acar, s. 11. Karş. Sirmen (2018), s. 633; Sirmen (2006), s. 218.

13 Diğer yandan, Tapu Sicili Tüzüğü'nün 31. maddesinin ikinci fikrasında, ipotekli alacağın devrinin yaratabileceği muhtemel sorunları önleyebilmek için alacağın devrinin düşünceler sütununda gösterileceği düzenlenmiştir. Ancak, ilgili düzenleme sadece bir düzen kuralı olduğundan aksine davranış devrin geçerliliğini etkilemeyecektir (Aktepe, s. 182; Ayan, s. 219). Bu şekilde, Türk Medenî Kanunu’nun 891. maddesinde yer alan düzenleme, ipotek hakkının alacağ 1 devralana geçmesi için bu hususun tapu siciline tescil edilmesinin şart olmadığı ve ipoteğin de alacak hakkıyla beraber devralana geçtiği şeklinde anlaşılmaktadır. Bkz. Acar, s. 11; Nomer/Ergüne, s. 47; Özçelik, s. 172. Nitekim Yargıtay kararları da bu yöndedir: "Yukarıda özetlenen dosya kapsamında, borçlunun üçüncü kişiyle yaptığı alacağın devri sözleşmesi ile alacağın temlik edildiği, bu durumda, temlik alınan kısım kadar ipotek hakkının da TBK'nun 189. maddesinde yer alan emredici düzenleme gereğince temlik alacaklısına geçeceği tabii olup, kanunun emredici hükmü gereğince alacağın devri ile bağlı haklardan olan ipotek hakkının da intikal edeceği gerçeği karşısında, mahkemenin, alacağın temliki ile birlikte ipoteğin devrinin geçerli olabilmesi için tapu siciline tescilinin gerekli olduğu yönündeki 
olmasının devamı olarak teminat altına alınan alacağın sona ermesi hâlinde ipoteğin de kendiliğinden sona ereceği, terkine kadar tapu sicilinde görünen ipoteğin sadece şeklî bir nitelik taşıdığı kabul edilmektedir ${ }^{14}$.

İpotek hakkı, -asıl alacak hakkına bağlılığı yanında- esasen alacak hakkı gibi "kişisel bir hak" niteliğinde de değildir. Diğer bir ifadeyle, ipotekli taşınmaz maliki olan ve fakat asıl alacak ilişkisinin borçlusu olmayan üçüncü kişinin ipotek miktarını borçlandığı söylenememekte; ipotek, bir alacak hakkı olarak kabul edilememektedir ${ }^{15}$. İpotekte, ipotekli taşınmaz maliki, sadece ipotek hakkı sahibinin alacağını elde edememesi hâlinde ipotek konusunun satılıp satış bedelinden alacağın karşılanmasına katlanma yükümlülüğü altındadır ${ }^{16}$. Bu durumda, ipotek hakkının, alacaklıya, taşınmaz malikine yönelik ayrı ve bağımsız bir kişisel hak, alacak hakkı bahşetmediği sonucuna varılabilir. Böylece ipotek hakkına, sadece teminatını oluşturduğu asıl alacak hakkının ödenmemesi hâlinde ve onunla bağlantılı olarak başvurulabilir.

İpoteğin asıl alacağa bağlı bir fer'î hak olması nedeniyle, ondan bağımsız olarak ipoteğin devredilmesi mümkün olmayıp ${ }^{17}$ asıl alacak hakkı sahibi ile ipotek hakkı sahibi her zaman aynı kişi olmak zorundadır ${ }^{18}$. Aksi hâlde, asıl alacak hakkından bağımsız bir ipotek hakkı meydana getirilmiş olur ki böyle bir sonuç sınırlı aynî haklara ilişkin tipe bağlılık ve sınırlı sayı ilkesine aykırılık teşkil eder $^{19}$.

gerekçesi yerinde değildir.” 12. HD, 17.04.2017, 14201/5881 <http://www.kazanci.com> s.e.t. 20.02.2019.

14 Bu konudaki görüşler ve detaylı bilgi için bkz. Tekinay, s. 107-108; Akipek, s. 227 vd; Saymen/Elbir, s. 626; Oğuzman/Seliçi/Oktay-Özdemir, s. 966; Nomer/Ergüne, s. 43; Ayan, s. 241; Özçelik, s. 183 vd; Aktepe, s. 183; Wolfgang/Zogg, Vor. Art 824-835, Rdnr. 4; Wieland, s. $640 \mathrm{vd}$.

15 Bu konudaki tartışmalar için bkz. Kuntalp, s. 291 vd.

16 Kuntalp, s. 292-293.

17 Çetiner (2015), s. 17, 134; Acar, s. 11, 67; Sirmen (2018), s. 633; Ayan, s. 219; Köprülü/Kaneti, s. 378; "Alacağın devri bakımından BK.nun 162. maddesinde sözü edilen şartlardan başka şartlar aramaya lüzum yoktur. Öte yandan fer' i haklardan olması dolayısiyle rehin hakları, genel hükümlere göre müstakilen değil, temin ettiği alacakla beraber temlik edilebilir. Bir başka deyimle alacaksız ipoteğin temliki mümkün değildir.” 14. HD, 28.12.1987, 9204/9266 <http://www.kazanci.com> s.e.t. 20.02.2019. Ayrıca bkz. Saymen/Elbir, s. 624 .

18 Köprülü/Kaneti, s. 378; Serozan, s. 312; Wolfgang/Zogg, Art. 824, Rdnr. 31; Wolf/Wellenhofer, $\$ 27$, Rdnr. 11; Lüke, $\$ 18$, Rdnr. 674 .

19 Özçelik, s. 172. Ayrıca bkz. Erel, Şafak N. (1982) Eşyaya Bağlı Borç, Ankara, Ankara Üniversitesi Siyasal Bilgiler Fakültesi, s. 9 vd, 74 vd; Saymen/Elbir, s. 556. 
O hâlde, ipotek hakkının -özellikle alacaklıya bahşettiği aynî teminat bakımından- asıl alacak hakkından ayrı bir hukukî önemi kabul edilse dahi, kullanılması ve hukukî işlemlere konu olması bakımından asıl alacaktan ayrı, ondan bağımsız bir mevcudiyetinin söz konusu olamayacağı sonucuna varılabilir.

\section{GENEL OLARAK HACİZ VE HACZEDİLEBİLECEK HAKLAR}

Haciz, borçlunun borcunu kendi arzusuyla ödememesi üzerine alacakl1nın talebiyle borçlunun borca yetecek mal ve hakkına Devlet aracılığıyla el konulmasıdır ${ }^{20}$. Kural olarak tüm malvarlığı ile sorumlu olan borçlunun kendi nezdindeki ve üçüncü kişilerdeki bütün taşınır, taşınmaz mal ve haklarına haciz konulabilir. Ancak, alacaklının alacağına kavuşmasını sağlarken, borçlunun ve ailesinin topluma muhtaç hâle düşmemesi, asgari bir yaşam standardını muhafaza etmesi, ekonomik varlığını devam ettirebilmesi gibi sosyal ve kamusal düşüncelerle borçlunun bazı mal ve haklarının haczedilemeyeceği kabul edilmiştir $^{21}$. Haczi caiz olmayan mallar İcra ve İflâs Kanunu'nun 82. maddesinde 12

20 Postacıŏlu, İlhan E./Altay, Sümer (2010) İcra Hukuku Esasları, 5. Baskı, İstanbul, Vedat, s. 359; Kuru, Baki (1988) İcra ve İflâs Hukuku, C:1, 3. Baskı, İstanbul, Alfa, s. 616; Kuru, Baki (2013) İcra ve İflâs Hukuku El Kitabı, 2. Baskı, Ankara, Adalet, s. 410; Pekcanıtez, Hakan/Atalay, Oğuz/Sungurtekin Özkan, Meral/Özekes, Muhammet (2011) İcra ve İflâs Hukuku, 9. Baskı, Ankara, Yetkin, s. 241; Muşul, Timuçin (2015) İcra ve İflâs Hukuku, 5. Baskı, Ankara, Adalet, s. 310; Muşul, Timuçin (2013) İcra ve İflâs Hukuku, C:1, 6. Baskı, Ankara, Adalet, s. 505; Karslı, Abdurrahim (2014) İcra Hukuku Ders Kitabı, 3. Baskı, İstanbul, Filiz, s. 278; Balkan, Yavuz (2009) Haczedilmezlik ve Benzer Müesseseler, Ankara, Seçkin, s. 17; Winkler, Thomas 'Fortsetzung der Betreibung' : Hunkeler, Daniel (Editör) (2014) Kurzkommentar SchKG, 2. Auflage, Basel, Helbing Lichtenhahn, Art. 89, Rdnr. 2; Spühler, Karl (2014) Shuldbetreibungs- und Konkursrecht, 6. Auflage, Genf, Schulthess, §27, Rdnr. 453.

21 Belgesay, Mustafa Reşit (1948) İcra ve İflâs Kanunu Şerhi, 2. Baskı, İstanbul, Cumhuriyet, s. 204; Ansay, Sabri Şakir (1954) Hukuk İcra ve İflâs Usulleri, 3. Baskı, Ankara, Yeni Cezaevi, s. 91-92; Berkin, Necmeddin M. (1957) 'Haczi Caiz Olmayan Eşya ve Alacaklar', İstanbul Barosu Dergisi, C:31, S:5, s. 114; Postacioğlu/Altay, s. 410; Kuru (1988), s. 779; Kuru, Baki (1962) 'Haczi Caiz Olmayan Şeyler', Ankara Üniversitesi Hukuk Fakültesi Dergisi, C:19, S:14, s. 278; Üstündăg, Saim (2004) İcra Hukukunun Esasları, 8. Baskı, İstanbul, s. 170-172; Uyar, Talih (1990) İcra Hukukunda Haciz, 2. Bask1, Manisa, Feryal, s. 468; Uyar, Talih (1974) 'Haczi Caiz Olmıyan Mallar ve Haklar', Recaî Seçkin'e Armağan, Ankara, Ankara Üniversitesi Hukuk Fakültesi, s. 552; Özbay, İbrahim (2005) 'İcra ve İflâs Hukukumuzda Haczedilmezlikten Feragat’ Erzincan Üniversitesi Hukuk Fakültesi Dergisi, C:9, S:1-2, s. 543; Özekes, Muhammet (2009) İcra Hukukunda Temel Haklar ve İlkeler, Ankara, Adalet, s. 114, 152, 178-179, 223; Pekcanıtez/Atalay/Sungurtekin Özkan ve diğerleri, s. 246; Şeker, Hilmi 
bent hâlinde ve tahdidi bir şekilde ve ayrıca bazı özel kanunlarda ${ }^{22}$ düzenlenmiştir. Bu düzenlemeler borçlunun tüm malvarlığının haczedilebileceği kuralına istisna olup, kıyas yoluyla genişletilemez ${ }^{23}$.

Haczedilmezliğe ilişkin bu kanunî düzenlemeler haricinde, icra hukuku ile haczin amaç ve niteliğinden kaynaklanan başka sınırlamalar da mevcuttur. Bu çerçevede, hacizde amaç, haczedilen malların satılarak alacaklının alacağına kavuşmasını sağlamak olduğuna göre, maddî hukuka göre başkasına devri caiz olmayan ${ }^{24}$, bedeli satış masraflarını karşılamayacak (İ̈K m. 85/5) veya maddî

(2008) 'Sürdürülebilir Yaşam, Sağlıklı Yaşlanma ve Haczedilmezlik', Legal Hukuk Dergisi, C:6, S:70, s. 3379; Yıldırım, M. Kâmil/Deren-Yıldırım, Nevhis (2012) İcra Hukuku, 5. Baskı, İstanbul, Beta, s. 141-142; Balkan, s. 25.

Benzer düşüncelerle borçluya ait bazı mal ve hakların haczedilemez olduğu yabancı hukuk sistemlerinde de düzenlenmiştir. Alman hukuku için bkz. Musielak, Hans-Joachim/Voit, Wolfgang/Becker, Udo (2018) Zivilprozessordnung, 15. Auflage, München, Vahlen, $₫ 811$, Rdnr. 1; Kindl, Johann/Meller-Hannich, Caroline/Wolf, Hans-Joachim (2015) Zwangsvollstreckung Handkommentar, 3. Auflage, Baden-Baden, Nomos, $\$ 811$, Rdnr. 1; Vorwerk, Volkert/Wolf, Christian/Forbriger: BeckOK ZPO, 31. Auflage, München 2018, $\$ 811$, Rdnr. 1. İsviçre hukuku için bkz. Kren Kostkiewicz, Jolanta 'Unpfändbare Vermögenswerte' : Hunkeler, Daniel (Editör) (2014) Kurzkommentar SchKG, 2. Auflage, Basel, Helbing Lichtenhahn, Art. 92, Rdnr. 1; Studer, Josef/Zöbeli, Markus (2015) Shuldbetreibungs- und Konkursrecht, 4. Auflage, Freiburg, Orell Füssli, s. 97-98; Vonder Mühll, Georges 'Unpfändbare Vermögenswerte' : Staehelin, Adrian/Bauer, Thomas/Staehelin, Daniel (Editörler) (2010) Basler Kommentar Bundesgesetz über Schuldbetreibung und Konkurs I, 2. Auflage, Basel, Helbing \& Lichtenhahn, Art. 92, Rdnr. 3.

226361 sayılı Finansal Kiralama, Faktoring ve Finansman Şirketleri Kanunu'nun 29. maddesinin 2. fikrasında finansal kiralama konusu malların; 5393 sayılı Belediye Kanunu'nun 15. maddesinin dokuzuncu fikrasında belediyeye ait bazı mal ve hakların; 5510 sayılı Sosyal Sigortalar ve Genel Sağlık Sigortası Kanunu'nun 93. maddesinin 1. fikrasında sigortalı ve hak sahiplerinin bu kanun gereği doğan gelir, aylık ve ödeneklerinin, prim borçları ve nafaka borçları haricinde; 5737 sayılı Vakıflar Kanunu'nun 15. maddesinin 1. fikrasında vakıflara ait hayrat taşınmazların ve 77. maddesinin 1. fikrasında Vakıflar Genel Müdürlüğü’ne ve mazbut vakıflara ait taşınmazların; 5199 sayılı Hayvanları Koruma Kanunu’nun 5. maddesinin 5. fikrasında ticarî amaç güdülmeden bilhassa ev ve bahçesi içerisinde bakılan ev ve süs hayvanlarının; 5809 sayılı Elektronik Haberleşme Kanunu'nun 34. maddesinin 1. fikrasında elektronik haberleşme hizmetleri ile ilgili olarak abone veya kullanıcılara tahsis edilen frekans, numara ve hat kullanımı ile internet alan adları gibi intifa ve kullanım hakları ile işletmecilerin yetkilendirmelerinin haczedilemeyeceği belirtilmiştir. Karslı, s. 288. Karşı görüşte Balkan, s. 25

24 “...İ̇ra ve İflas Kanunu'nda düzenlenmemekle birlikte, maddi hukuk kurallarına göre, bir kısım mal ve hakların da haczi mümkün değildir. Buna göre, maddi hukuka göre başkasına devri yasak olan mal ve haklar da haczedilemez." 12. HD, 30.11.2017, 23575/14997 
bir değeri olmayan mal ve hakların haczi caiz değildir ${ }^{25}$. Aksi hâlde, haciz müessesesi, alacaklının alacağına kavuşmasını sağlamaktan ziyade ${ }^{26}$ borçluya psikolojik bir baskı yapmak amacıyla kullanılacaktır ki icra sisteminin böyle bir sonuca hizmet edemeyeceğine şüphe yoktur.

Özellikle haczedilen malın paraya çevrilerek alacaklının tatmin edilmesi gerektiğinden, maddî bir değeri olmayan ve satış (paraya çevirme) yoluyla üçüncü kişilere devredilemeyecek mal ve hakların haczedilemeyeceği işin doğası gereğidir. Bu kapsamda yer alan malvarlığı değerleri sadece somut varlığ bulunan taşınır ve taşınmaz mallar değil, borçluya ait malvarlığı değerleri kapsamında yer alan alacak ve sair tüm haklardır. Borçluya ait somut bir varlığ bulunmayan birtakım hakların haczedilebileceği ve paraya çevrilebileceğine İcra ve İflâs Kanunu'nun çeşitli maddelerinde yer verilmiş olmasina rağmen (İIK m. 88, 89, 120), bu hakların genel bir kriter olan belirttiğimiz şartları da sağlaması gerektiğine şüphe yoktur. Örneğin, oturma hakkı (TMK m. 823/2) ile diğer irtifak hakları (TMK m. 838/2) başkasına devredilemeyeceğinden haciz de edilemez ${ }^{27}$. Bu çerçevede yine bir sınırlı aynî hak olarak intifa hakkının hac-

<http://www.kazanci.com> s.e.t. 20.02.2019; "Bir şeyin haczedilip haczedilemeyeceği -yasalardaki özel hükümler dışında- o şeyin 'devredilip edilememe' niteliği belirlendiğinden, başka bir deyişle ancak devri mümkün (serbest) olan şeyler haczedilebilir.” 12. HD, 04.05.2007, 6560/9012 <http://www.kazanci.com> s.e.t. 20.02.2019. Aynı yönde 17. HD, 09.02.2016, 8021/1347 <http://www.kazanci.com> s.e.t. 20.02.2019; HGK, 27.01.2016, 13-684/106 <http://www.kazanci.com>s.e.t. 20.02.2019; HGK, 27.05.2015, 12-2274/1486

$<$ http://www.kazanci.com> s.e.t. 20.02.2019.

Aynı kural Alman hukukunda kanunen düzenlenmiștir. Söz konusu düzenlemenin, icra hukukunun maddî hukukla ilgilisi ve maddî hukuk kurallarıyla uyumuna işaret ettiği belirtilmektedir. Bu konuda bkz. Kindl/Meller-Hannich/Wolf, $\$ 851$, Rdnr. 1; Musielak/Voit/Becker, $₫ 851$ Rdnr. 1; BeckOK ZPO/Riedel, $\$ 851$ Rdnr. 1.

25 Ansay, s. 67, 84 vd.; Postacioğlu/Altay, s. 412; Kuru (1988), s. 778-779; Kuru (1962), s. 277 278; Kuru (2013), s. 501-502; Uyar (1974), s. 551, 555; Pekcanıtez/Atalay/Sungurtekin Özkan ve diğerleri, s. 245-246; Mușul (2013), s. 504, 537; Ulukapı, Ömer (1995) 'Haczedilmezlik ve Haczedilmezliğin '4046 Sayılı Özelleştirme Kanunu' Kapsamındaki Uygulaması', Banka ve Ticaret Hukuk Dergisi, C:18, S: 1-2, s. 137-138; Üstündağ, s. 170-173; Yıldırım/Deren-Yıldırım, s. 139; Kren Kostkiewicz (2014b), Art. 92, Rdnr. 2; Spühler, $\$ 27$, Rdnr. 463; Kren Kostkiewicz, Jolanta (2014) Schuldbetreibungs- und Konkursrecht, 2. Auflage, Genf, Schulthess, s. 173; Vonder Mühll, Art. 92, Rdnr. 1-2.

26 Vonder Mühll, Art. 92, Rdnr. 1.

27 Kuru (2013), s. 502. 
zedilebileceği açıç̧a düzenlenmiş olmasına rağmen (İIK m. 83), sadece kullanılması başkasına devredilebilen intifa haklarının ${ }^{28}$ haczedilebilir olduğu kabul edilmektedir ${ }^{29}$.

\section{III. İPOTEK HAKKININ HACZİ İLE İLGİLİ SORUN, UYGULAMA ve YARGITAY KARARLARI}

\section{A. SORUNUN TESPITI}

Çalışmamızın önceki bölümlerinde borçluya ait hangi hakların haczinin mümkün olduğu üzerinde durulmuş ve bu çerçevede özellikle ipotek hakkı gibi diğer birtakım sınırlı aynî hakların hangi şartlar altında haczedilebileceğine kısaca değinilmiştir. Yukarıda da ifade edildiği gibi, sınırlı aynî hakların haczedilebilir olabilmesi için her şeyden önce devredilebilir nitelikte olması gerekir. $\mathrm{Bu}$ çerçevede, bir takip borçlusunun üçüncü bir kişiden olan alacağının teminatı olan ipotek hakkının haczi konusuna tereddütle yaklaşmak gerekir. Daha açık bir ifadeyle, alacaklı A icra takibinin borçlusu B'nin Ü'den olan belirli bir miktar alacağını icra hukuku kuralları çerçevesinde çeşitli yollarla haczedebilir. Ancak, Ü’nün B’ye olan borcu için aynî teminat olarak B lehine tesis edilen ipotek hakkının, ipotekli taşınmazın Ü veya başka bir üçüncü kişiye ait olması önemli olmaksızın, ayrı ve bağımsız bir hakmışçasına haczi ve paraya çevrilmesi eleştiriye açık bir uygulamadır. Özellikle, ipotekli taşınmaz malikinin borçtan şahsen sorumlu olmayan bir kişi olması hâlinde, ipoteğin paraya çevrilmesi yoluyla takipte malik ve asıl borçlunun şeklî mecburî takip arkadaşı olması ${ }^{30}$, icra hukuku

28 Böyle bir durumda dahi devredilebilecek olan bizzat intifa hakkının kendisi değil; TMK m. 806 çerçevesinde intifa hakkının kullanılmasıdır. Bu nedenle, bizatihi intifa hakkının haczinden değil; intifa hakkının kullanılmasından elde edilen semerelerin haczinden söz etmek daha yerinde olacaktır. Bu konuda detaylı bilgi için bkz. Saymen/Elbir, s. 521; Akipek, s. 86 vd; Özen, Burak (2008) Türk Medeni Hukukunda Eşya Üzerinde İntifa Hakkı, İstanbul, Vedat, s. $293 \mathrm{vd}$.

Kuru (2013), s. 447; Üstündağ, s. 174; Muşul (2013), s. 563; Muşul (2015), s. 335.

Örneğin, 12. HD, 24.09.2018, 4145/8533 <http://www.kazanci.com> s.e.t. 20.02.2019; 12. HD, 05.07.2018, $10525 / 7456$ <http://www.kazanci.com> s.e.t. 20.02.2019; 12. HD, 02.07.2018, 3763/7041 <http://www.kazanci.com> s.e.t. 20.02.2019; 12. HD, 20.03.2018, 29839/2784 <http://www.kazanci.com> s.e.t. 20.02.2019. Ayrica bkz. Kuru, Baki (1993) İcra ve İflâs Hukuku, C:3, 3. Bask1, İstanbul, Alfa, s. 2400, 2411; Kuru (2013), s. 997-998; Üstündağ, s. 72; Dişel, Buse (2014) İcra Hukukunda Takip Arkadaşlı̆̆ı, İstanbul, Oniki Levha, s. 101. 
kuralları bakımından da ipotek hakkıyla asıl hakkın bir arada işlemlere tâbi tutulması gerektiğine örnek olarak gösterilebilir.

Nitekim, asıl alacağa bağlı bir sınırlı aynî hak olan ipotek hakkının maddî hukuka göre tek başına devredilmesi ve müstakil bir hak olarak tedavülü kabul görmemektedir. O hâlde, aynî bir teminat olarak ipotek, teminatını oluşturduğu asıl alacaktan tamamen bağımsız ve ayrı bir hukukî statüye sahip değildir. $\mathrm{Bu}$ nedenlerle, devredilebilirlik noktasında asıl alacaktan ayrılamayan ipotek hakkının, haczedilebilirlik bakımından da aynı koşullara tâbi olması gerektiği kanaatindeyiz. Ancak uygulamada, takip borçlusunun üçüncü kişiden alacağ 1 için tapuya tescil edilmiş ipotek hakkına müstakilen haciz işlemleri yapıldığı ve Yargıtay kararlarının da bu uygulamayı desteklediği görülmektedir. Bu hususta aşağıda ayrıntılı açıklama ve değerlendirme yapılmış; ayrıca, ipotekle teminat altına alınan bir alacak hakkının haczinin söz konusu ipoteğe etkisi üzerinde durulmuştur.

\section{B. UYGULAMA VE YARGITAY'IN KONUYLA İLGILİ GÖRÜŞÜ}

Aşağıda belirtilen somut Yargitay kararlarından ve şu an hâlen derdest icra dosyalarından yaptığımız araştırmalar çerçevesinde mevcut uygulamanın ipotek hakkının haczine cevaz verme yönünde olduğunu söyleyebiliriz. Uygulamada karşılaştığımız bu haciz işlemlerinin tamamı Yargıtay aşamasına vararak somut bir yüksek yargı kararına konu olamasa da, mevcut icra hukuku işleyişimizin genel olarak ipotek hakkının haczedilebileceğini kabul etme yönünde olduğu, aşağıda belirttiğimiz somut kararlardan da anlaşılmaktadır.

Yargıtay 12. Hukuk Dairesi'nin çeşitli kararlarında, alacaklının, borçlunun üçüncü bir kişiden olan alacağının teminatı olarak tescil edilen ipotek hakkının haczinin mümkün olduğ $\mathrm{u}^{31}$ açıcça ifade edilmektedir. Aynı ifadelerle ipo-

31 "İpotek, kişisel bir alacağın teminat altına alınması amacını güden ve bir taşınmazın değerinden alacaklının alacağını elde etmesi olanağını sağlayan sınırlı bir ayni haktır. Haciz ise, kesinleşmiş bir icra takibinin konusu olan belli bir para alacağının ödenmesini sağlamak için, bu yolda talepte bulunan alacaklı lehine, söz konusu alacağı karşılayacak miktar ve değerdeki borçluya ait mal ve haklara, icra müdürü tarafından el konulmasıdır. Sınırlı ayni hakların 
tek hakkının haczinin mümkün olduğunun vurgulandığı farklı dairelerden verilmiş daha yeni tarihli kararlar da mevcuttur ${ }^{32}$. Bu durumda, ipotek hakkının haczi yönündeki taleplerin kabul gördüğü mevcut uygulamanın hâlen Yargitay tarafından da desteklendiği sonucuna varılabilir. Bu yöndeki kararların gerekçesi olarak, sınırlı aynî hakların haczinin mümkün olduğu ve ipoteğin de bu kapsamda bir sınırlı aynî hak olduğu; ayrıca, ipotek hakkının haczedilemeyeceğine ilişkin özel bir düzenlemenin de mevcut olmadığı vurgulanmaktadır.

Konuyla ilgili diğer bir Yargıtay kararına ${ }^{33}$ konu olan olayda ise, borçlunun, üçüncü bir kişiden olan alacağının teminatı olarak lehine konulan ipotek hakkının haczi talep edilmiş; ancak, tapu idaresince haczin doğrudan taşınmazlar üzerine işlenmesi nedeniyle alacaklının şikâyet yoluna başvurandan herhangi bir alacağının da olmadığı belirtilerek icra mahkemesine başvurulmuştur. Karar metninde, ilk derece mahkemesinin kararına yapılan atıflardan anlaşıldığ 1 kadarıla icra mahkemesince, ipotek alacağının fer'i haklardan olması nedeniyle rehin haklarının müstakilen değil, temin ettiği alacakla birlikte temlik edilebileceği, somut olayda ipotekten kaynaklı bir alacağın henüz doğmamış bulunması ve kural olarak ileride doğacak alacaklara haciz konulamayacă̆ı gerekçesiyle şikâyetin kabulü ile ipotek hakkı üzerine konulan haczin kaldırılmasına karar verilmiştir. Yargıtay, taşınmaz üzerine konulan hacizlerin kaldırılmasının talep edilmesine rağmen, ipotek hakkı üzerine konulan hacizlerin kaldırılmış olmasının taleple bağlılık ilkesine aykırı olduğu gerekçesiyle ilgili ilk derece

haczi mümkün olduğundan, sınırlı ayni hak niteliğinde olan borçlunun sahip bulunduğu bir ipotek hakkı da haczedilebilir. Haczin tamamlanması için ipotek hakkının haczedildiğinin tapu siciline şerh verilmesi yeterlidir. İpotek hakkının haczedilemeyeceğine ilişkin yasal bir engel de bulunmamaktadır. Bu durumda, ipotek hakkının haczedilmesinde yasaya uymayan bir yön bulunmamaktadır.” 12. HD, 14.11.2013, 2013/26641, 2013/36040 http://www.kazanci.com azanci.com" http://www.kazanci.com s.e.t. 20.02.2019. Aynı yönde 12. HD, 17.04.2017, $14201 / 5881$ <https://www.lexpera.com.tr> s.e.t. 21.02.2019; 12. HD, 12.01.2016, 23049/333 <http://www.kazanci.com> s.e.t. 20.02.2019; 12. HD, 19.02.2014, 1685/4640 <http://www.kazanci.com> s.e.t. 20.02.2019; 12. HD, 05.06.2012, 789/19311 https://www.lexpera.com.tr s.e.t. 21.02.2019; 12. HD, 01.11.2013, 24026/34330 <https://www.lexpera.com.tr> s.e.t. 21.02.2019.

32 Örneğin, "Sınırlı ayni hakların haczi mümkün olduğundan, sınırlı ayni hak niteliğinde olan borçlunun sahip bulunduğu bir ipotek hakkı da haczedilebilir." 20. HD, 20.02.2018, $11084 / 1190<$ http://www.kazanci.com> s.e.t. 20.02.2019.

33 12. HD, 28.03.2014, 2014/5002, 2014/9159<http://www.kazanci.com> s.e.t. 20.02.2019. 
mahkemesi kararını bozmuştur. Söz konusu kararda, -her ne kadar somut olaya uygun olmayabilirse de- özellikle ilk derece mahkemesinin kararına konu edilen gerekçeler konumuz bakımından önem arz etmektedir. Zira mahkeme, ipotek hakkının müstakilen devredilemeyeceğini ve sadece teminata konu alacak hakkıyla birlikte devredilebileceğini belirterek böyle bir alacağın mevcut olmaması hâlinde ipotek hakkına da haciz konulamayacağı sonucuna varmaktadır. Ayrıca burada mahkemenin, esasen ipotekle teminat altına alınan alacak haczedilmeden ipotek hakkının da haczedilemeyeceği yönündeki görüşe de yaklaştığı söylenebilecektir.

Bu noktada, esasen ilgili alacak hakkı usûlüne uygun bir şekilde haczedilmesine rağmen ayrıca ve açıkça tapuya tescil edilmiş ipotek hakkının da haczinin gerekip gerekmediği hususu büyük bir önemi haizdir.

\section{KONUYA İLİ̧̧KIN DEĞERLENDİRME VE GÖRÜŞÜMÜZ}

\section{A. İPOTEĞİN TEMINATINI OLUŞTURDUĞU ASIL ALACAK ÇER- ÇEVESİNDE DEĞERLENDİRME}

Asıl alacak usûlüne uygun bir şekilde haczedilmişse, bu alacağın paraya çevrilmesi süresinde alacaklılar gerekirse İcra ve İflâs Kanunu'nun 120. maddesine göre alacakları yetkiye dayanarak ilgili alacağa bağlı olan ipotek hakkı için de ipoteğin paraya çevrilmesi yoluyla takibe başvurabilir ${ }^{34}$. Bunun için alacaklıların ayrıca ve açıcça tapudaki ipotek hakkı üzerine haciz talep ve icra etmelerine gerek yoktur ve hatta alacaklıların bu yöndeki haciz talepleri maddî hukukta kabul gören ipotek hakkının tek başına devredilemez olduğu gerekçesiyle reddedilmelidir. Nitekim, maddî hukuk bakımından da ipoteğin tek başına bir

34 Bulut, Uğur (2013) İcra Hukukunda Ödeme Yerine Alacakların Devri (İİK m. 120), Ankara, Adalet, s. 244.

İpotek hakkının haczedilebileceği yönündeki Yargıtay kararlarında da haciz sahibi alacaklının icra dairesinden alabilecekleri yetkiyle ipoteğin paraya çevrilmesi yoluyla takibe başvurabilecekleri belirtilmelidir: "Alacaklı tarafından borçlu hakkında kambiyo senetlerine özgü haciz yolu ile yapılan Ankara 26. İcra Müdürlügünün 2007/5384 sayılı icra takip dosyasında borçlunun şikayetçiye ait taşınmaz üzerindeki ipotek hakkına haciz konmuş ve buna dayanarak alınan 13.04.2012 tarihli yetki belgesi ile şikayetçi hakkında Ankara 26. İcra Müdürlügünün 2012/8076 esas sayılı dosyasından ipoteğin paraya çevrilmesi yolu ile ilamlı icra takibi yapılmıştır." 12. HD, 25.03.2014, 5833/8697 <https://www.lexpera.com.tr> s.e.t. 21.02.2019. 
işleme konu olamayacağı, devredilemeyeceği ve tedavül edemeyeceği vurgulanmaktadır ${ }^{35}$. Bu çerçevede ipotek hakkının tek başına haczedilemeyeceği sonucunu da kabul etmek gerekmektedir. Aksi hâlde, asıl alacaktan bağımsız olarak ve ayrı bir şekilde haczedilen ipotek hakkının paraya çevrilmesinde hukuken açıklanması mümkün olmayan sonuçlarla karşılaşılabilir. Örneğin, ipoteğin konusunu oluşturan alacak başka takip alacaklıları tarafından daha önce haczedilmiş olmasına rağmen bir şekilde başka bir alacaklı tarafından ipotek hakkına haciz şerhi işletilir ve ipoteğin paraya çevrilmesi imkânı da bu alacaklıya tanınırsa, aynî teminatın konusunu oluşturan alacak hakkını daha önce haczettirmiş takip alacaklıları -aslında alacak hakkını haczetmekle ilgili alacağın teminatına da başvurma hakkını haiz olmalarına rağmen- sonradan ipotek hakkına haciz talep eden diğer takip alacaklılarına kıyasla daha geride kalabilir. Bu nedenle, alacağın iradî devrinde dahi ipotek hakkına ayrıca tapuya tescil verilmesine ihtiyaç duyulmamasına rağmen (TMK m. 891), haciz işlemleri bakımından böyle bir haciz şerhine ihtiyaç ve hatta özellikle ilgili alacak hakkının haczinden bağımsız olarak imkân dahi yoktur.

\section{B. DİĞER TEMINNAT AMAÇLI İŞLEMLER ÇERÇEVESINNDE DE- ĞERLENDİRME}

İpotek hakkının tek başına haczedilemeyeceği yönündeki görüşümüzü destekleyici başka bir husus da şahsî teminat olarak kefalettir. Aynî teminat olan ipotek için yukarıda değinilen yargı kararlarına, şahsî teminat olarak kefalet için rastlanılmamaktadır. Zira, takip borçlusunun bir alacağının haczedilmesi haricinde, bu alacaktan ayrı ve bağımsız olarak devredilebilecek olan kefilden olan alacak hakkından söz edilememektedir ${ }^{36}$. Nasıl ki, haczedilen alacak hakkının paraya çevrilmesi sürecinde ilgili alacağa şahsen teminat veren kefile

Acar, s. 67. Ayrica bkz. yuk. I-II.

36 Bu durum, kefalet, rehin ve ipotek gibi fer’i hak niteliğindeki teminatların genel bir özelliğidir. Bu konuda bkz. Tekinay, s. 70-71; Çetiner (2015), s. 17 vd; Serozan, s. 310; Acar, s. 37 vd; Çetiner, Bilgehan (2016) 'Geniş Kapsamlı Teminat Amacı Açıklamalarının Geçerliliği Sorunu', Marmara Üniversitesi Hukuk Fakültesi Hukuk Araştırmaları Dergisi, C:22, S:3, s. 810 vd. Kefalet için ayrıca bkz. Özen, Burak (2017) Kefalet Sözleşmesi, 4. Baskı, İstanbul, Vedat, s. $88 \mathrm{vd}$. 
başvurulabiliyorsa, benzer şekilde bir aynî teminat olan ipotek (ve hatta rehin) hakkı için de aynı sonuçları kabul etmek gerekmektedir.

$\mathrm{Bu}$ noktada teminat mektubu ve teminat mektubundan kaynaklanan hakkın haczi bakımından ortaya çıkan içtihatlar da önemi haizdir. Yargıtay, teminat mektubunun kıymetli evrak niteliğinde olmadığını ve lehdarın teminat mektubundan kaynaklanan mevcut bir hakkının bulunmadığını ve teminat mektubu hangi iş için verilmişse sadece $o$ iş için haczedilerek paraya çevrilebileceğini belirtmektedir ${ }^{37}$. Söz konusu içtihat doğrudan ipotek için uygulanabilir olmasa dahi, ipoteğin teminatını oluşturduğunu alacağa bağlı olma ve birlikte işlemlere tâbi tutulma zorunluluğu noktasında dikkate alınabilecektir. Nasıl ki teminat mektubu ${ }^{38}$ sadece verildiği iş için paraya çevrilebilecekse, aynî bir teminat olan ipotek hakkı da yalnızca verildiği alacak hakkının tahsili için paraya çevrilebilecektir. Dolaylı olarak, ipotek hakkının ipotek alacaklısının başka bir borcu için paraya çevrilmesi kabul görmemelidir.

37 "Teminat mektuplarının kıymetli evrak niteliği bulunmamaktadır. Banka ile muhatap arasında garanti sözleşmesi niteliğinde olan teminat mektubunda lehtar, akit durumda değildir. Yani, teminat mektubu ile doğmuş ve doğacak bir hak bulunmadığından, lehdarın borcu için teminat mektubunun haczedilmesine yasal imkan yoktur. Teminat mektubu hangi iş için verilmiş ise onun için haczedilip paraya çevrilebilir.” 8. HD, 03.10.2016, 26001/13002 < http://www.kazanci.com> s.e.t. 20.02.2019. Aynı yönde 8. HD, 21.06.2013, 10111/9740 $<$ http://www.kazanci.com> s.e.t. 20.02.2019; 12. HD, 28.05.2008, 8131/10806 <http://www.kazanci.com> s.e.t. 20.02.2019; 12. HD, 05.07.2002, 13462/14707 $<$ http://www.kazanci.com> s.e.t. 20.02.2019.

38 Teminat mektubunun hukukî niteliği ipotek veya kefaletten ayrılmakta ve üçüncü kişinin fiilini taahhütü içeren garanti sözleşmesi niteliğinde kabul edilmektedir (bkz. İBK, 27.12.2017, 2016/1, 2017/6 <www.kazanci.com> s.e.t. 21.02.2019). Bu nedenle, esasen teminat mektubunda asıl ilişkiden bağımsızlık söz konusudur. Ancak, bizatihi teminat mektubunun kendisinin haczedilemeyeceği, sadece teminat mektubuna dayanan alacak hakkının haczinin mümkün olduğu kabul edilmektedir. Diğer bir deyişle, sadece teminat mektubunun konusunu oluşturan risk gerçekleştiği takdirde doğacak alacak hakkı haczedilebilir. İlgili teminat mektubunun konusunu oluşturan riskten, teminat amacından bağımsız olarak bizatihi teminat mektubunun haczi mümkün değildir. Bu konuda detaylı açıklamalar için bkz. Sav, Atilâ (1967) 'Banka Teminat Mektuplarının Haczi', Ankara Barosu Dergisi, S:1, s. 48-50; Ünlïtepe, Mustafa (2012) 'Banka Teminat Mektubundan Doğan Alacağın Devri ve Haczi' İstanbul Barosu Dergisi, C:86, S:3, s. 194 vd. Ayrıca karş. Zeren, Yıldırım (1966) 'Banka Teminat Mektuplarının Hukukî Mahiyeti ve Hacizlerinin Caiz Olup Olmadığı Meselesi’, Ankara Barosu Dergisi, S:5, s. 869-871. 


\section{HACZİ KABUL EDİLMEYEN DİĞER HAKLAR ÇERÇEVESİNDE DEĞERLENDİRME}

Haczedilebilirlik açısından yukarıda belirttiğimiz sınırlamalarda, Yargıtay'ın birçok kararında belirtilen maddî hukuka göre devredilebilir nitelikte olmayan mal ve hakların haczedilemeyeceği kuralı da dikkate alınmalıdır. Zira, sınırlı bir aynî hak olan ipoteğin teminat altına alınan alacaktan bağımsız ve ayrı bir hak olarak kabul edilerek başkalarına devredilmesi maddî hukukta kabul görmemektedir. Ayrıca yine haczedilebilirliğe ilişkin yukarıda belirtilen s1nırlamalar haricinde, devredilebilir, maddî bir değeri olan ve haczi kabil olmayan mal veya haklar arasında sayılmayan her hakkın haczinin de mümkün olamayacağı belirtilmektedir. Bazı haklar, ilgili hakların doğası gereği haczedilemezdir. Örneğin, kira sözleşmesinin kiracıya bahşettiği hak, hizmet sözleşmesinden kaynaklanan işçinin edimi, vekâlet sözleşmesinde vekilin üstlendiği hizmet veya önalım hakkı (bağlı olduğu pay haczedilmedikçe) doğası gereği haczedilemez haklardır ${ }^{39}$. İpotek hakkı bakımından da bu haklara benzer bir şekilde haciz hâlinde ipoteğin niteliğiyle bağdaşmayan sonuçlar ortaya çıkmaktadır. Zira, ipotek bakımından maddî hukukta geçerli olan en temel ilkelerden biri olan belirlilik ilkesi, bu hakkın başka bir alacak için haczi ve paraya çevrilmesi hâlinde zedelenmiş olacaktır. Söz konusu ilkeye göre, ipotek şeklindeki teminatın konusunu oluşturan alacağın belirli veya belirlenebilir olması gere$\mathrm{kir}^{40}$. Teminat verenin teminat amacına yönelik irade açıklaması kapsamında kabul edilemeyecek alacaklar nedeniyle teminat konusu taşınmazın paraya çevrilmesi ipoteğin niteliğiyle bağdaştırılamaz. Bu nedenle, ipotek hakkının, teminatını oluşturduğu alacağın tahsiline yönelik işlemler yapılmaksızın, asıl alacaktan ayrı ve bağımsız bir şekilde; doğrudan, alacaklının üçüncü bir kişiye olan başka bir borcunun tahsili amacıyla haczedilmesi ve paraya çevrilmesi kabul edilemez.

39 Postacıoğlu/Altay, s. 413; Üstündağ, s. 172, 175-176; Kren Kostkiewicz (2014b), Art. 92, Rdnr. 6; Kren Kostkiewicz (2014a), s. 175.

40 Bu konuda detaylı bilgi için bkz. Tekinay, s. 72 vd; Akipek, s. 188 vd; Saymen/Elbir, s. 574 vd; Gürsoy/Eren/Cansel, s. 960 vd; Serozan, s. 315-319; Çetiner (2015), s. 101 vd; Acar, s. 44 vd; Nomer /Ergüne, s. 21 vd; Sirmen (2018), s. 582 vd; Ayan, s. 166 vd; Çetiner (2016), s. $805 \mathrm{vd}$. 


\section{GÖRÜŞÜMÜZ}

Yukarıda çeşitli bakış açılarıyla kıyasen değerlendirmeye çalıştığımız üzere, ipotek hakkının bağımsız olarak haczinin caiz olmadığı kanaatindeyiz. Takip borçlusunun üçüncü bir kişiden olan alacağının teminatı olan ipoteğe başvurulabilmesi için öncelikle söz konusu alacak hakkının haczinin gerektiği ve bu hacizden başka tapudaki ipotek hakkına haciz işlemi uygulanmasının mümkün ve gerekli olmadığını belirtmek isteriz. Daha açık bir ifadeyle, ipotek hakkının haczinin mümkün olmadığını belirtirken, esasen bu ipotek hakkına sadece teminatı olan alacağın haczi ve paraya çevrilmesi işlemleriyle başvurulabileceğini vurgulamak istemekteyiz ${ }^{41}$. Konuyla ilgili bir Yargıtay kararında da zımnî de olsa benzer sonuçlara varılmıştır. Karara konu somut olayda, tapu sicilinde borçlu lehine görünen ipotek hakkına haciz şerhi işlenmiş olmasına rağmen, ipoteğin teminat altına aldığı alacak hakkının daha önceki bir tarihte devredildiğinin ispatlanması hâlinde -alacağın devriyle birlikte ipotek hakkı da kendiliğinden devralana geçtiği için- ipotek hakkına konulan haciz şerhinin de devir oranında iptali gerektiği ifade edilmiştir ${ }^{42}$. O hâlde, Yargıtay da aslında

${ }^{41}$ Yargıtay uygulaması da esasen ipotek hakkı ile teminat altındaki alacak hakkının ayırmama yönündedir. Zira, ipotek hakkına haciz şerhinin işlenmesini müteakiben, takip borçlusunun borçlusuna borcun vadesi geldiğinde icra dairesine ödenmesine dair muhtıra gönderilebileceği ifade edilmektedir. Ancak bu uygulama da, özellikle asıl borçlu ile ipotekli taşınmazın malikinin farklı kişiler olduğu durumlarda sorunlara neden olabilecektir. Bu nedenle, ipotek hakkının ayrı ve bağımsız bir hak olarak haczi yerine asıl alacağın hacziyle beraber ipoteğin korunması yönteminin benimsenmesinin daha yerinde olabileceği kanaatindeyiz. İlgili karar için bkz: "Sınırlı ayni hakların haczi mümkün olduğundan, sınırlı ayni hak niteliğinde olan borçlunun sahip bulunduğu bir ipotek hakkı da haczedilebilir. Haczin tamamlanması için ipotek hakkının haczedildiğinin tapu siciline şerh verilmesi yeterlidir. İpotek hakkının haczedilemeyeceğine ilişkin yasal bir engel de bulunmamaktadır. Bu durumda, ipotek hakkının haczedilmesinde ve icra müdürlüğünce bu hacze istinaden 3. kişiye, ipoteğin vadesi geldiğinde borcun, borçlu yerine icra dosyasına ödenmesi gerektiğini bildiren muhtıra gönderilmesinde yasaya uymayan bir yön olmadığı gibi, 3.kişinin bu konudaki muhtıranın iptalinde hukuki yararı da bulunmamaktadır. O halde mahkemece şikayetin reddi yerine yazılı şekilde kabulü isabetsizdir.” 12. HD, 05.06.2012, 789/19311 <https://www.lexpera.com.tr> s.e.t. 21.02.2019.

42 "Somut olayın incelenmesinde, .... İcra Dairesi'nin 2013/7093 Esas sayılı dosyasında, toplam 7.000.000 TL alacağın tahsili için başlatılan takipte, borçlunun üçüncü kişilerden olan alacağı için lehine tesis edilen ipoteğe 13.01.2016 tarihinde haciz konulduğu, Kadıköy 15. Noterliği'nin 26.06.2013 tarih 17185 yevmiye sayllı temlikname ile 2.000.000 TL bedelli alacak ve ipoteğin temlik alan lehine tesis edildiğinin belirtildiği, borçlunun ipotek üzerindeki haczin 
tapudaki ipotek hakkının tek başına haczinin, alacaklıya bağımsız bir hak bahşetmeyeceği ve bu haczin sadece geçerli bir alacak hakkının varlığı durumunda anlam ifade edeceği sonucuna varmaktadır. Bu durumda, haciz bakımından da tapudaki ipotek hakkı değil, bu hakkın bağlı bulunduğu alacak hakkının önemli olduğu sonucuna varmak söz konusu kararda ifade edilen düşüncelerin doğal bir sonucudur.

Takip alacaklılarının haczedilen alacak hakkının teminatı olan ipoteğe başvurusu bakımından, yukarıda belirtilen ilgili alacak hakkının devri hâlinde uygulama alanı bulan yeni alacaklının düşünceler sütununda belirtilmesi ${ }^{43}$ şeklinde bir işlem kabul edilebilir ${ }^{44}$. Tapu Sicili Tüzüğ̈̈nün 31. maddesine göre, alacağın devri ve benzeri işlemler düşünceler sütununda belirtilebilmekte; ancak, devrin burada belirtilmemesi alacağın devri ve bu sayede alacağın teminatı olan ipotek hakkına başvurulabilmesi için zorunlu bir şart olarak kabul edilmemektedir ${ }^{45}$. Benzer şekilde, takip borçlusunun üçüncü bir kişideki alacak hakkı usûlüne uygun bir şekilde haczedilirse, ilgili alacak hakkının teminatı olan ipotek hakkının korunması için alacağın haczedildiğinin tapu sicilinin düşünceler

kaldırılmasını talep ettiği, icra müdürlügünce talebinin reddine karar verildiği, şikayet üzerine icra mahkemesinin şikayetin reddine karar verildiği anlaşılmıştır. Yukarıda özetlenen dosya kapsamında, borçlunun üçüncü kişiyle yaptığı alacağın devri sözleşmesi ile alacağın temlik edildiği, bu durumda, temlik alınan kısım kadar ipotek hakkının da TBK'nun 189. maddesinde yer alan emredici düzenleme gereğince temlik alacaklısına geçeceği tabii olup, kanunun emredici hükmü gereğince alacağın devri ile bağlı haklardan olan ipotek hakkının da intikal edeceği gerçeği karşısında, mahkemenin, alacağın temliki ile birlikte ipoteğin devrinin geçerli olabilmesi için tapu siciline tescilinin gerekli olduğu yönündeki gerekçesi yerinde değildir. O halde mahkemece, şikayetin kabulüne karar verilmesi gerekirken, yazılı gerekçe ile istemin reddi yönünde hüküm tesisi isabetsizdir.” 12. HD, 17.04.2017, 14201/5881 $<$ https://www.lexpera.com.tr> s.e.t. 21.02.2019.

Bkz. yuk. dn. 12.

44 Alman hukukunda konuyla ilgili açı kanunî düzenlemeler mevcuttur (ZPO $\$ 830$ vd). İcra hukukuna ilişkin söz konusu düzenlemeler, Alman Medeni Kanunu'nun 1153. paragrafinda alacak hakkının ipotek devredilmeksizin veya ipoteğin alacak devredilmeksizin tek başlarına devredilemeyeceğine ilişkin açık kanunî yasakla uyum içerisindedir. Bu konuda bkz. Musielak/Voit/Becker, $₫ 830$, Rdnr. 1 vd; Kindl/Meller-Hannich/Wolf, $₫ 830$, Rdnr. 1 vd; BeckOK ZPO/Riedel, $\$ 830$ Rdnr. 1.

45 Tapu Sicili Tüzüğü’nün 31. maddesi sadece bir düzen kuralı olduğundan aksine davranış devrin geçerliliğini etkilemeyecektir (Aktepe, s. 182; Ayan, s. 159, 219). Bu şekilde, ipotek hakkının alacağı devralana geçmesi için bu hususun tapu siciline tescil edilmesinin şart olmadığı ve ipoteğin de alacak hakkıyla beraber devralana geçtiği kabul edilmektedir. Bkz. Acar, s. 11; Nomer/Ergüne, s. 47; Özçelik, s. 172. 
sütununda belirtilmesi uygun olabilir. Kanaatimizce, Tapu Sicili Tüzügü’nün 31. maddesinde sınırlayıcı bir ifadenin tercih edilmemiş olması, özellikle alacağın devri ve benzeri işlemlerin düşünceler sütununda belirtilebileceğinin düzenlenmiş olması kapsamında böyle bir haciz işleminin bildirilmesi mümkün olmalıdır. Ancak bu işlem, alacak hakkının haczinin geçerli olması ve bu çerçevede paraya çevirme aşamasında alacak hakkının teminatı olan ipoteğe başvurulabilmesi için zorunlu bir işlem olarak kabul edilemez. Böyle bir uygulama hem ipotek hakkının tek başına haczinin, haczedilebilir haklara ilişkin genel kurallara aykırı sonuçlarını ortadan kaldıracak hem ipoteğin niteliğiyle uyumlu olacak hem de takip alacaklıların haczedilen alacağın teminatlarına başvurabilme imkânlarını açıklığa kavuşturabilecektir.

\section{SONUÇ}

İcra hukukunda haciz kurumuyla borçlunun malvarlığ değerlerine hukuken el konularak alacaklının belirli bir para alacağına kavuşması amaçlanır. Haczedilen mal ve haklar, paraya çevirmeye ilişkin kurallar uyarınca satılarak elde edilen değer alacağına karşılık olarak alacaklıya ödenir. İcra hukuku sistemimiz, alacaklının alacağına kavuşması amacı yanında borçlunun topluma muhtaç hâle gelmesini engelleme, sosyal ve ekonomik varlığını devam ettirebilme amacina hizmet etmektedir. Bu nedenle, çeşitli kanunlarda ve özellikle İcra ve İflâs Kanun'unda borçlunun birtakım mal ve haklarının haczedilemez olduğu düzenlenmiştir.

Haczi caiz olmayan mal ve haklara ilişkin açık kanunî düzenlemeler haricinde, icra hukukunun ve haciz kurumunun amacından hareketle maddî hukuka göre devri mümkün olmayan, maddî bir değeri olmayan veya değeri satış ve paylaştırma giderlerini dahi karşılayamayacak malların haczedilemeyeceği kabul görmektedir. Bu durum, haczedilmezliğe ilişkin kanunî düzenlemeler haricinde, genel olarak borçlunun bütün malvarlığ değerleri için geçerli olan bir ilkedir. Örneğin devri kabil olmayan bir mal veya hak üçüncü bir kişiye devredilemeyeceği için paraya çevirme aşamasında satışı mümkün olamayacak ve neticede parasal bir gelirin elde edilerek alacaklıya ödenmesi amacına ulaşılamayacaktır. 
Bu kapsamda borçlunun üçüncü bir kişiden olan belirli bir alacağının teminatı olarak gösterilen ipotek hakkı, maddî hukukta geçerli olan ilkeler gereği tek başına haciz ve paraya çevirme işlemlerine tâbi tutulamamalıdır. Zira ipotek hakkının, teminat altına alınan alacaktan bağımsız olarak tedavül kabiliyeti yoktur; bu hak, sadece teminatını oluşturduğu alacak hakkıyla birlikte işlemlere konu edilebilir. Keza aynı şekilde, ipotekle teminat altına alınan alacak hakkını devralan üçüncü kişiler de özel olarak ipotek hakkıyla ilgili tapuda herhangi bir işleme ihtiyaç olmaksızın (ve hatta bu husus diğer fer'î teminatlar için de geçerlidir) ipotek hakkına başvurabilme hakkına sahiptirler. Bu nedenlerle, icra hukuku çerçevesinde de borçlunun üçüncü kişiden olan alacağ haczedilmeksizin bizatihi bu alacağın teminatı olarak tapudaki ipotek hakkının haczi kabul edilmemelidir. Borçlunun üçüncü kişilerdeki alacak hakkının haczi çerçevesinde yapılacak işlemler neticesinde yetkilendirilen takip alacaklıları veya alacağı icradan devralan üçüncü kişiler, bu alacağın tahsil edilmesi sürecinde zaten ilgili ipotek hakkına da başvurma haklarına sahiptirler. Diğer bir ifadeyle, ipotek hakkının asıl alacaktan bağımsız olarak haczi ne caizdir ne de gereklidir. Asıl alacağın haczedilmesi hâlinde, bu alacağın paraya çevrilmesi aşamasında zaten alacağın teminatı olan ipoteğin paraya çevrilmesi mümkündür. 


\section{KAYNAKÇA}

Acar, Faruk (2015) Rehin Hukuku Dersleri, İstanbul, Vedat.

Akipek, Jale G. (1974) Türk Eşya Hukuku (Aynî Haklar), Üçüncü Kitap Mahdut Aynî Haklar, Ankara, Sevinç.

Akipek, Jale G./Akıntürk, Turgut (2009) Eşya Hukuku, İstanbul, Beta.

Aktepe, Sezin (2007) 'İpoteğin Alacağa Bağlı Hak Olması ve Diğer Özellikleri' İstanbul Ticaret Üniversitesi Sosyal Bilimler Dergisi, S:12, s. 177-193.

Altay, Sümer/Eskiocak, Ali (2007) Türk Medeni Hukukunda Taşınmaz Rehni, İstanbul, Vedat.

Ansay, Sabri Şakir (1954) Hukuk İcra ve İflâs Usulleri, 3. Baskı, Ankara, Yeni Cezaevi.

Ayan, Mehmet (2017) Eşya Hukuku III Sınırlı Aynî Haklar, 8. Baskı, Ankara, Seçkin.

Aybay, Aydın/Hatemi, Hüseyin (2012) Eşya Hukuku, 3. Baskı, İstanbul, Vedat.

Ayiter, Nuşin (1977) Eşya Hukuku, Ankara, Sevinç.

Balkan, Yavuz (2009) Haczedilmezlik ve Benzer Müesseseler, Ankara, Seçkin.

Barlas, Nami (2003) 'Yeni Medenî Kanunun Aynî Teminatlara İlişkin Düzenlemeleri', Bilgi Toplumunda Hukuk, Ünal Tekinalp’e Armağan, C:2, İstanbul, Beta, s. 569-588.

Belgesay, Mustafa Reşit (1948) İcra ve İflâs Kanunu Şerhi, 2. Baskı, İstanbul, Cumhuriyet.

Berkin, Necmeddin M. (1957) 'Haczi Caiz Olmayan Eşya ve Alacaklar', İstanbul Barosu Dergisi, C:31, S:5.

Bertan, Suad (1976) Aynî Haklar, C:2, Ankara, Balkan.

Budak, Ali Cem (2010) İpoteğin Paraya Çevrilmesi Yoluyla Takip, 3. Baskı, İstanbul, Oniki Levha.

Bulut, Uğur (2013) İcra Hukukunda Ödeme Yerine Alacakların Devri (İIK m. 120), Ankara, Adalet. 
Çetiner, Bilgehan (2016) 'Geniş Kapsamlı Teminat Amacı Açıklamalarının Geçerliliği Sorunu’, Marmara Üniversitesi Hukuk Fakültesi Hukuk Araştırmaları Dergisi, C:22, S:3, s. 803-826.

Çetiner, Bilgehan (2015) Taşınmaz Teminatı, İstanbul, Filiz.

Dişel, Buse (2014) İcra Hukukunda Takip Arkadaşlı̆̆ı, İstanbul, Oniki Levha.

Erel, Şafak N. (1982) Eşyaya Bağlı Borç, Ankara, Ankara Üniversitesi Siyasal Bilgiler Fakültesi.

Ernst, Wolfgang/Zogg, Samuel 'Die Grundpfandverschreibung': Honsell, Heinrich/Vogt, Nedim Peter/Geiser, Thomas (Editörler) (2011) Bundesgesetz über Schuldbetreibung und Konkurs I, 2. Auflage, Basel, Helbing \& Lichtenhahn.

Esener, Turhan/Güven, Kudret (2015) Eşya Hukuku, 6. Baskı, Ankara, Yetkin.

Gödde, Walter (1980) Grundpfandrechte, Wiesbaden, Springer.

Gürsoy, Kemal T./Eren, Fikret/Cansel, Erol (1984) Türk Eşya Hukuku, 2. Baskı, Ankara, Ankara Üniversitesi Hukuk Fakültesi.

Karslı, Abdurrahim (2014) İcra Hukuku Ders Kitab1, 3. Baskı, İstanbul, Filiz.

Kindl, Johann/Meller-Hannich, Caroline/Wolf, Hans-Joachim (2015) Zwangsvollstreckung Handkommentar, 3. Auflage, Baden-Baden, Nomos.

Köprülü, Bülent/Kaneti, Selim (1982) Sınırlı Aynî Haklar, 2. Baskı, İstanbul, Fakülteler.

Kren Kostkiewicz, Jolanta (2014) Schuldbetreibungs- und Konkursrecht, 2. Auflage, Genf, Schulthess.

Kren Kostkiewicz, Jolanta 'Unpfändbare Vermögenswerte' : Hunkeler, Daniel (Editör) (2014) Kurzkommentar SchKG, 2. Auflage, Basel, Helbing Lichtenhahn.

Kuntalp, Erden (1995) 'Teminat Kavramı, Teminat Türleri ve Bunlardan Doğan Sorumluluk', Reha Poroy'a Armağan, İstanbul, İstanbul Üniversitesi Hukuk Fakültesi, s. 263-299.

Kuru, Baki (1988) İcra ve İflâs Hukuku, C:1, 3. Baskı, İstanbul, Alfa. 
Kuru, Baki (1993) İcra ve İflâs Hukuku, C:3, 3. Baskı, İstanbul, Alfa.

Kuru, Baki (2013) İcra ve İflâs Hukuku El Kitabı, 2. Baskı, Ankara, Adalet.

Kuru, Baki (1962) 'Haczi Caiz Olmayan Şeyler', Ankara Üniversitesi Hukuk Fakültesi Dergisi, C:19, S:1-4, s. 277-326.

Lüke, Wolfgang (2018) Sachenrecht, 4. Auflage, München, C.H.Beck.

Musielak, Hans-Joachim/Voit, Wolfgang/Becker, Udo (2018) Zivilprozessordnung, 15. Auflage, München, Vahlen.

Muşul, Timuçin (2015) İcra ve İflâs Hukuku, 5. Baskı, Ankara, Adalet.

Muşul, Timuçin (2013) İcra ve İflâs Hukuku, C:1, 6. Baskı, Ankara, Adalet.

Nomer, Haluk Nami/Ergüne, Mehmet Serkan (2016) Eşya Hukuku, C: II Rehin Hukuku, İstanbul, Oniki Levha.

Ŏguzman, M. Kemal/Seliçi, Özer/Oktay-Özdemir, Saibe (2018) Eşya Hukuku, 21. Baskı, İstanbul, Filiz.

Özbay, İbrahim (2005) 'İcra ve İflâs Hukukumuzda Haczedilmezlikten Feragat' Erzincan Üniversitesi Hukuk Fakültesi Dergisi, C:9, S:1-2, 543-567.

Özçelik, Ş. Barıș (2017) 'İpoteğin Alacağa Bağlılığı', Banka ve Ticaret Hukuku Dergisi, C:33, S:4, s. 157-188.

Özen, Burak (2017) Kefalet Sözleşmesi, 4. Baskı, İstanbul, Vedat.

Özen, Burak (2008) Türk Medeni Hukukunda Eşya Üzerinde İntifa Hakkı, İstanbul, Vedat.

Özekes, Muhammet (2009) İcra Hukukunda Temel Haklar ve İlkeler, Ankara, Adalet.

Pekcanıtez, Hakan/Atalay, Oğuz/Sungurtekin Özkan, Meral/Özekes, Muhammet (2011) İcra ve İflâs Hukuku, 9. Bası, Ankara, Yetkin.

Postacioğlu, İlhan E./Altay, Sümer (2010) İcra Hukuku Esasları, 5. Baskı, İstanbul, Vedat.

Saymen, Ferit H./Elbir, Halid K. (1954) Türk Eşya Hukuku (Aynî Haklar), İstanbul, Akgün. 
Schmid, Jörg/Hürlimann-Kaup, Bettina (2012) Sachenrecht, 4. Auflage, Zürich-Basel-Genf, Schulthess.

Serozan, Rona (2006) 'Taşınmaz Rehni', İstanbul Üniversitesi Hukuk Fakültesi Mecmuası, C:64, S:2, s. 301-324.

Sirmen, A. Lâle (2018) Eşya Hukuku, 6. Baskı, Ankara, Yetkin.

Sirmen, Lale (2006) 'İpotekli Alacağın Devredilmesi ile İlgili Bazı Sorunlar', Ticaret Hukuku ve Yargitay Kararları Sempozyumu XXII, 15 Aralık 2006, s. 213-223.

Spühler, Karl (2014) Shuldbetreibungs- und Konkursrecht, 6. Auflage, Genf, Schulthess.

Studer, Josef/Zöbeli, Markus (2015) Shuldbetreibungs- und Konkursrecht, 4. Auflage, Freiburg, Orell Füssli.

Şeker, Hilmi (2008) 'Sürdürülebilir Yaşam, Sağlıklı Yaşlanma ve Haczedilmezlik', Legal Hukuk Dergisi, C:6, S:70, s. 3379-3392.

Şener, Yavuz Selim (2010) Türk Hukukunda İpotek ve Uygulaması, 3. Baskı, Ankara, Adalet.

Tekinay, Selâhattin Sulhi (1994) Menkul Mülkiyeti ve Sınırlı Aynî Haklar, İstanbul, Filiz.

Ulukapı, Ömer (1995) 'Haczedilmezlik ve Haczedilmezliğin ‘4046 Sayılı Özelleştirme Kanunu’ Kapsamındaki Uygulaması', Banka ve Ticaret Hukuk Dergisi, C:18, S: 1-2, s. 137-150.

Uyar, Talih (1974) 'Haczi Caiz Olmıyan Mallar ve Haklar', Recaî Seçkin’e Armağan, Ankara, Ankara Üniversitesi Hukuk Fakültesi.

Uyar, Talih (1990) İcra Hukukunda Haciz, 2. Baskı, Manisa, Feryal.

Ünlütepe, Mustafa (2012) 'Banka Teminat Mektubundan Doğan Alacağın Devri ve Haczi’ İstanbul Barosu Dergisi, C:86, S:3, s. 181-200.

Ünlütepe, Mustafa (2012) 'İpoteğin Alacak Hakkı Bakımından Kapsamı', Türkiye Barolar Birliği Dergisi, S:102, s. 173-218.

Üstündağ, Saim (2004) İcra Hukukunun Esasları, 8. Baskı, İstanbul.

Sav, Atilâ (1967) 'Banka Teminat Mektuplarının Haczi', Ankara Barosu Dergisi, S:1, s. 48-50. 
Vonder Mühll, Georges 'Unpfändbare Vermögenswerte' : Staehelin, Adrian/Bauer, Thomas/Staehelin, Daniel (Editörler) (2010) Basler Kommentar Bundesgesetz über Schuldbetreibung und Konkurs I, 2. Auflage, Basel, Helbing \& Lichtenhahn.

Vorwerk, Volkert/Wolf, Christian (2018) BeckOK ZPO, 31. Auflage, München, C.H.Beck (BeckOK ZPO/Yazar).

Wieland, Carl Albert (1909) Das Sachenrecht des schweizerischen Zivilgesetzbuchs, Zürich, Schulthess (Çeviren: Karafaki, İ. Hakkı (1946) Aynî Haklar, Ankara, Yeni Cezaevi).

Winkler, Thomas 'Fortsetzung der Betreibung' : Hunkeler, Daniel (Editör) (2014) Kurzkommentar SchKG, 2. Auflage, Basel, Helbing Lichtenhahn.

Wolf, Manfred/Wellenhofer, Marina (2018) Sachenrecht, 33. Auflage, München, C.H.Beck.

Yıldırım, M. Kâmil/Deren-Yıldırım, Nevhis (2012) İcra Hukuku, 5. Baskı, İstanbul, Beta.

Zeren, Yıldırım (1966) 'Banka Teminat Mektuplarının Hukukî Mahiyeti ve Hacizlerinin Caiz Olup Olmadığı Meselesi', Ankara Barosu Dergisi, S:5, s. 869-871. 